\title{
Flujos migratorios e inversión directa en el extranjero: España en el proceso de globalización
}

Pilar Rodríguez Martínez

Universidad de Almería

\section{RESUMEN}

En la literatura actual, los movimientos migratorios y las inversiones directas en el extranjero no se suelen considerar conjuntamente. En el presente artículo tratamos de ubicar a España en el proceso de globalización en base a esos dos elementos. Desde nuestro punto de vista, el perfil de España como país de inmigración no puede ser entendido sin tener en cuenta el efecto de la internacionalización de la economía española a partir de la entrada en la Unión Europea. Nos detenemos en el análisis de la combinación de esos dos factores para mostrar cómo en un contexto de globalización el papel del Estado sigue siendo fundamental, aunque su rol se ha hecho más complejo desarrollando, por un lado, políticas de control de los movimientos migratorios internacionales y, por otro, propiciando la expansión de las inversiones directas en el extranjero. Como ejemplo, desarrollamos el caso de las relaciones entre España y Marruecos en la última década.

Palabras clave: Migraciones Internacionales, Globalización, Inversiones Extranjeras, España, Marruecos. 


\section{INTRODUCCIÓN}

Hemos escuchado tantas veces la idea de que vivimos en una «aldea global» que cada vez tenemos más dificultades para descifrar lo que eso significa. A veces da la impresión de que todos los ciudadanos del planeta habitasen en la misma aldea y que, por tanto, las fronteras fueran superfluas. Según algunos autores, el proceso de globalización ha conducido a una progresiva irrelevancia de los Estados nacionales. En ese proceso, «a medida que los mercados globales crecen, se rompe el equilibrio en detrimento de la autonomía y el espacio de acción de los actores estatales en materia de política económica. A la vez, los Estados-nación encuentran en las corporaciones multinacionales a unos poderosos competidores» (Habermas, 2000: 105) ${ }^{1}$.

En este artículo argumentaremos justamente en sentido contrario: vivir en una aldea global no significa que desaparezcan las fronteras, y mucho menos los Estados, aunque éstos hayan modificado significativamente sus actuaciones. Más en concreto, nos ocuparemos de las conexiones entre dos procesos: las migraciones internacionales de nacionales de países en vías de desarrollo hacia países desarrollados y las inversiones que los países desarrollados realizan en esos países. Nuestro objetivo es mostrar que en estos procesos el papel de los Estados sigue siendo fundamental. En este sentido, coincidimos con Peter Gowan cuando argumenta que la mayor parte de la literatura que se ha escrito sobre la globalización tiende a dar por bueno un supuesto profundamente incrustado en el pensamiento liberal, a saber, que la relación entre el poder de los mercados (y las fuerzas de mercado) y el poder de los Estados se caracteriza principalmente por el antagonismo ${ }^{2}$.

Entendemos por globalización de las migraciones la tendencia a que un mayor número de países se vean afectados por los movimientos migratorios al mismo tiempo (Castles y Mi-

\footnotetext{
1 Alain Touraine, por ejemplo, señala que «lo que denominamos política, la gestión de los asuntos de la ciudad o de la nación, se ha descompuesto de la misma manera que el yo individual. Gobernar un país consiste hoy día antes que nada en hacer compatible su organización económica y social con las exigencias del sistema económico internacional, mientras que las normas sociales se debilitan y las instituciones se hacen cada vez más modestas, liberando un espacio creciente para la vida privada y las asociaciones voluntarias. ¿Cómo se puede hablar todavía de la ciudadanía y de la democracia representativa mientras que los que son elegidos miran hacia el mercado mundial y los electores hacia su vida privada? El espacio intermedio no está siendo ocupado sino por llamamientos cada vez más conservadores a valores y a instituciones que están siendo superados por la práctica» (Touraine, 1997: 18; la traducción es nuestra). Zygmunt Bauman también afirma que «la globalización, en su forma actual significa pérdida de poder de los Estados nacionales y (por el momento) ausencia de cualquier sustituto eficaz» (Bauman, 2001: 2 de 4).

2 En esta línea, consideramos, con Peter Gowan, que «del mismo modo que el Estado juega un papel central en los asuntos monetarios y financieros internos, ya sea el régimen nacional de estructura Keynesiana o neoliberal, también el Estado o los Estados más importantes juegan un papel central en los asuntos monetarios y financieros internacionales. El hecho de que estas continuas intervenciones políticas en aspectos cruciales de la economía internacional no suelan reflejarse en mucha de la literatura sobre la misma es el resultado de anteojeras ideológicas, tanto más poderosas al hallarse arraigadas por la división del trabajo profesional y académico existente entre las ciencias políticas y económicas. Estas anteojeras son evidentes en aquellas definiciones de globalización que sostienen que se trata meramente de una fuerza técnico-económica, no sólo ajena a los controles político-estatales, sino incluso opuestos a éstos» (Gowan, 2000: 51-52).
} 
Iler, 1993: 8; Blanco, 2000). Ciertamente, como se destaca desde la Organización Internacional del Trabajo, haciéndose eco de los diferentes patrones migratorios de 152 países, y considerando la proporción de emigrantes y de inmigrantes, así como el volumen de las remesas, entre 1970 y 1990 el número de países que pueden ser considerados como principales receptores ha subido de veintinueve a cincuenta y cinco. Ha aumentado el número de países que son al mismo tiempo principales receptores y emisores de población, que ha crecido de cuatro a quince (Stalker, 2000: 7).

Pero, por otro lado, hay que tener en cuenta que los movimientos de personas a escala mundial no son comparables ni de lejos con la globalización de los mercados de mercancías y capitales. Como señala Stalker, «el comercio y las finanzas se están moviendo en cantidades mucho más impresionantes: en 1996 las exportaciones globales de bienes representaban sobre un $29 \%$ de los Productos Nacionales Brutos, y el flujo de la inversión directa extranjera llegaba a alcanzar el $6 \%$ del total de la inversión nacional. Por otro lado, la migración global de trabajo es mucho más limitada, suponiendo sólo sobre 120 millones de personas —equivalentes al 2,3\% de la población mundial» (Stalker, 2000: 1) 3 $^{3}$. La observación de Stalker parece del todo pertinente pues contrapone cara a cara dos procesos que durante un tiempo han sido percibidos por separado: la movilidad del capital y la movilidad de las poblaciones a escala internacional. Aquí nos ocuparemos de la inserción de España en esos dos procesos de globalización.

Esta exposición comenzará recordando la visión de los economistas clásicos y neoclásicos sobre el asunto de las migraciones para mostrar cómo a partir de los años setenta del pasado siglo se produjo un viraje en los planteamientos sobre la necesidad de controlar los flujos migratorios. A partir de ahí retomaremos la hipótesis de Sassen sobre la relación entre inversiones directas en el extranjero y flujos migratorios, para contrastar lo que, a nuestro juicio, podría haber ocurrido en los últimos años en el caso español. Mostraremos cómo a medida que España ha ido extendiendo su radio de acción económica hacia los países en vías de desarrollo, como por ejemplo Marruecos, ha empezado a recibir migrantes precisamente de esa misma procedencia. En ese proceso el papel del Estado español no ha sido precisamente irrelevante.

\section{LOS PLANTEAMIENTOS DE LOS ECONOMISTAS CLÁSICOS Y NEOCLÁSICOS SOBRE LOS FLUJOS MIGRATORIOS}

Los economistas clásicos creían que las migraciones debían ser reguladas y asistidas por los Estados. Se trataba de una de las pocas excepciones respecto a su radical defensa del

\footnotetext{
${ }^{3}$ La traducción es nuestra.
} 
principio del laissez-faire. Como explica Thomas (1973: 1-14), a finales del siglo XVIII y durante el siglo XIX, cuando los flujos migratorios que partían de Gran Bretaña hacia EE.UU. y Canadá crecían con el desarrollo de los barcos de vapor, Adam Smith, David Ricardo o Stuart Mill creían que el gobierno debía financiar el asentamiento de la mano de obra británica en las colonias para que los empresarios británicos no tuvieran que pagar los costos de desplazamiento de los trabajadores. Argumentaban que no había ninguna garantía de que los trabajadores, una vez arribaran al nuevo territorio, permanecieran trabajando para esos empresarios. Los economistas clásicos reservaban el laissez-faire para el intercambio de bienes y servicios dentro de sus fronteras, al tiempo que propugnaban el intervencionismo estatal en favor de lo que se denominaba una «teoría dinámica de la colonización».

Hay que decir que Marx no se preocupó demasiado por rebatir esas argumentaciones. En El Capital llevó a cabo una crítica demoledora a Malthus y su Essay on Population ${ }^{4}$ donde se establecía el «principio de la población »5. Según Marx, la última palabra sobre el volumen de la población de un país depende de la producción y acumulación capitalistas ${ }^{6}$. En su argumentación, el ejército de reserva contemplaba la posibilidad de que se produjeran migraciones. Según Marx, el capitalismo creaba su propio ejército de reserva para desenvolverse libremente, puesto que no le bastaba con la fuerza de trabajo disponible en un determinado momento. El capital dividía así a la clase obrera entre ejército activo y ejército de reserva, tanto por el aumento y la disminución del volumen relativo de la superpoblación como por el grado en que se absorbía unas veces y se liberaba otras ${ }^{7}$.

4 Marx trata a Malthus de este modo: «si el lector me recordase el nombre de Malthus, cuyo Essay on Population apareció en 1798, le diría que este escrito no es en su primera forma nada más que un plagio escolarmente superficial y curescamente declamatorio de Defoe, Sir James Stuart, Townsend, Franklin, Wallace, etc., y no contiene una sola frase pensada por él mismo» (1976: 74).

5 Según el conocido principio de población que allí establecía Malthus, la población crece a ritmo geométrico mientras que los recursos lo hacen a un ritmo aritmético, de donde se deducía la necesidad de establecer algún tipo de control para impedir el crecimiento de la población. El autor proponía, entre otras medidas, el celibato y la abstinencia sexual, para impedir que los pobres se multiplicaran.

6 Dice Marx: «imagínese la insensatez de la sabiduría económica que predica a los obreros adaptar su número a las necesidades de valorización del capital. El mecanismo de la producción y la acumulación capitalistas adapta constantemente este número a estas necesidades de valorización. La primera palabra de esta adaptación es la creación de una superpoblación relativa o ejército industrial de reserva, la última palabra la miseria de capas cada vez más extensas del ejército obrero activo y el peso muerto del pauperismo» (Marx, 1976: 111-112).

7 Entre las diversas formas de superpoblación relativa -ejército de reserva - indicaba Marx que se daban tres: la fluctuante (obreros varones que se ven despedidos en masa, puesto que han dejado atrás la edad juvenil, y que se ven obligados a emigrar), la latente (población rural que en cualquier momento puede transformarse en proletariado urbano) y la estancada (su característica es el máximo de trabajo y el mínimo de salario; se trata principalmente de trabajadores a domicilio que constituyen una masa «sobrante», y también hay que incluir aquí la esfera del pauperismo compuesta por vagabundos, criminales, prostitutas, en fin, por el lumpen-proletariado, a los huérfanos hijos de pobres, y a los degradados, encanallados e incapaces de trabajar). Este ejército de reserva, según Marx, «presiona durante los períodos de estancamiento y prosperidad media, sobre el ejército activo de obreros y frena sus reivindicaciones durante el período de superproducción y paroxismo. La superpoblación relativa es, pues, el fondo sobre el que se mueve la ley de la oferta de trabajo» (Marx, 1976: 104). 
Para Marx, como para los marxistas posteriores, los flujos migratorios eran una variable dependiente del capital.

Ravenstein fue uno de los primeros científicos sociales que aportó datos estadísticos sobre los flujos migratorios ${ }^{8}$. Siguiendo la corriente de pensamiento de los economistas de su tiempo, pensaba que las emigraciones eran una de las mejores maneras de expandir la civilización occidental allende los mares. Las famosas leyes sobre las migraciones fueron formuladas a finales del siglo XIX con el claro convencimiento de que se estaba contribuyendo a aportar conocimientos para expandir el radio de acción del imperio británico 9 .

La cuarta ley sobre las migraciones, un tanto olvidada, reclamaba que cada corriente de emigración genera su contracorriente de compensación. Si nos vamos a los textos de Ravenstein, podemos darnos cuenta de que esa «ley» se basaba en la observación de que si bien en lugares como Irlanda se perdía población a causa de las migraciones, no obstante, hacia ciudades como Dublín también se desplazaban pequeños comerciantes y empresarios para establecer sus negocios. Esta corriente de compensación generaba nuevos centros a partir de los cuales se difundiría la «civilización». En el segundo de sus escritos, que trata sobre las migraciones en el resto de países europeos, se clasificaba a los países en dos grupos: los que perdían y los que ganaban población mediante los flujos migratorios. Para Ravenstein, las migraciones significaban vida y progreso. Un país o condado cuya población fuera sedentaria sería una zona estancada (Ravenstein, 1889: 288).

Con el paso de los años la cuarta ley fue quedando aparcada. La construcción de Occidente como centro generador y destino de los cambios que en el mundo merecían ser analizados hizo que los científicos sociales, tanto funcionalistas como marxistas ${ }^{10}$, incurrieran en

8 Las Laws of migration aparecen en dos escritos que leyó ante la Statistical Society en 1885 y 1889 y fueron publicados en el Journal of the Statistical Society. En el primero estudia las migraciones en el seno del Reino Unido y, en el segundo, en el resto de Europa, EE.UU. y Canadá.

9 En 1885, Ravenstein planteaba sus leyes del siguiente modo: «1. La mayoría de las migraciones se producen a corta distancia (...) hacia centros de comercio e industria (...) 2. (...) El proceso de absorción de migrantes se produce del siguiente modo: los habitantes del campo que rodea a una ciudad en crecimiento son los primeros en emigrar; el hueco que dejan en la población rural se cubre con migrantes de distritos más remotos, hasta que la fuerza de atracción de una de las crecientes ciudades hace sentir su influencia, paso a paso, hasta el lugar más remoto del Reino (...). Las facilidades de las comunicaciones pueden suplir las desventajas de las distancias. 3. El proceso de dispersión es el reverso de la absorción y exhibe características similares. 4. Cada corriente de migración principal produce una contracorriente de compensación. 5. Los migrantes que proceden de largas distancias generalmente se dirigen a los grandes centros de comercio e industria. 6. Los nativos de las ciudades son menos migradores que los de las partes rurales de la región. 7. Las mujeres son más migradoras que los hombres» (Ravenstein, 1885: 198-199). La traducción es nuestra.

10 Una crítica al etnocentrismo de las teorías funcionalistas y marxistas se puede encontrar en el libro Modernización: un análisis sociológico, de Carlota Solé (1976). 
un sesgo etnocentrista y, por supuesto, androcentrista ${ }^{11}$. Como consecuencia de esos planteamientos, a partir de los años cincuenta los flujos migratorios internacionales han venido a quedar definidos como aquellos movimientos de trabajadores varones procedentes de los países en vías de desarrollo que se desplazaban hacia los países occidentales ricos.

En nuestro país, algunos investigadores ya han señalado que las condiciones circunstanciales que unos determinados grupos de migrantes padecen no son inherentes al fenómeno migratorio mismo (Ruiz de Olabuénaga y Blanco, 1994: 15) ${ }^{12}$. Ciertamente, las investigaciones parecían encontrar su justificación en el desvelamiento e incluso la denuncia de unas condiciones sociales concretas, pero al fijar la atención exclusivamente en los grupos procedentes de países en desarrollo parece que daban por hecho que las migraciones habían de originarse necesariamente en esas circunstancias. Tanto las «aves de paso» de Piore como otras sugerentes teorizaciones sobre los movimientos internacionales de personas que se escribieron desde principios de los años setenta ${ }^{13}$, han analizado exclusivamente los movimientos migratorios que surgían en los países en desarrollo y que tenían como destino los países desarrollados.

11 La séptima ley de Ravenstein merece ser especialmente resaltada como una de las más tergiversadas en las sucesivas reformulaciones, hasta llegar a nuestros días donde se afirma, basándose en Ravenstein, todo lo contrario de lo que él afirmó. Hemos llegado así a dar por bueno que el hecho de que las mujeres participen en las migraciones supone un «descubrimiento», un «adelanto» o incluso una novedad histórica. Por ejemplo, Castles y Miller afirman que «en el pasado la mayoría de las migraciones laborales y muchos movimientos de refugiados estaban dominados por los hombres, y las mujeres generalmente intervenían en ellos como reunificación familiar. Desde los años sesenta, las mujeres han jugado un rol más importante en las migraciones laborales: por ejemplo, las mujeres turcas frecuentemente precedían a sus maridos a Alemania. Hoy día las mujeres trabajadoras de la mayoría de los movimientos tan diversos como los de Cabo Verde a Italia, Filipinas hacia Oriente Medio y tailandeses a Japón. Algunos movimientos de refugiados, incluyendo los de Yugoslavia, están marcados por una mayoría de mujeres. La feminización de las migraciones se basa en cuestiones nuevas que tienen que ver con quienes desarrollan las políticas y con los que estudian los procesos migratorios» (Castles y Miller, 1993: 8-9). La traducción es nuestra.

12 El concepto de migrante no siempre supuso unas determinadas condiciones sociales. En el caso español, Giner y Salcedo afirmaban en 1976 que «una teoría adecuada de la migración tiene, pues, que empezar por abandonar la obsesión por el trasvase de población rural a la urbana, o la de países pobres a los industrializados y tener en cuenta otros aspectos clave. Las migraciones étnico ocupacionales (tenderos hindúes en Canarias y Barcelona, comerciantes libaneses en las costas africanas, cocineros y lavanderos chinos en América) no son ni mucho menos casos marginales...» (Giner y Salcedo, 1976: 122123). Proponen, también, que se estudien las «burguesías migratorias».

13 A escala internacional, las referencias que, a nuestro juicio, son obligadas desde una perspectiva marxista serían el libro de Castles y Kösack, Inmigrants Workers and Class Structure in Western Europe (1985); el artículo de Manuel Castells, «Inmigrant Workers and Class Struggles in Advanced Capitalism: the Western European Experience» (1975), y la reformulación de M. J. Piore, Birds of Passage: migrant labour in Industrial Societies (1979). Desde la perspectiva de la teoría de sistemas inspirada en el funcionalismo habría que resaltar el artículo de Mabogunje, «Systems Approach to a Theory of Rural-Urban Migration», de 1970. Por parte de los economistas neoclásicos hay que resaltar las aportaciones de Michael Todaro en El desarrollo económico del Tercer Mundo, traducida al castellano en 1988; el artículo de Oded Stark, «Discontinuity and the Theory of International Migration», de 1984, y su libro La migración del trabajo, también traducido al castellano en 1993. Para una visión panorámica de las diferentes teorías sobre las migraciones sigue siendo fundamental el artículo de Douglas Massey, Joaquín Arango y otros, «Theories of International Migration: A Review and Appraisal», de 1993. También hay que recordar que Joaquín Arango ha llevado a cabo una actualización de la panorámica internacional en un artículo que lleva por título «Enfoques conceptuales y teóricos para explicar la migración», del año 2000. 
A partir de los años ochenta, economistas neoclásicos como Todaro ${ }^{14}$ señalan que esos movimientos migratorios de trabajadores, tanto los internos como los internacionales, no podían ser considerados ya como positivos ${ }^{15}$. Según Todaro, «debemos reconocer, antes que nada, que la emigración que supera los puestos de trabajo disponibles es, tanto un síntoma del subdesarrollo del Tercer Mundo como un factor que contribuye a este subdesarrollo» (Todaro, 1988: 304).

Se argumenta que, en el contexto de los años ochenta, las migraciones internacionales de trabajadores no benefician ni al país emisor ni al receptor. En lo que tiene que ver con el país receptor, las migraciones no son positivas, puesto que aumentan el desempleo, la competitividad y los costes sociales derivados de una mayor población. En lo que se refiere al país emisor, aporta varios argumentos. En primer lugar, no suponen una reducción del desempleo, puesto que emigran los más cualificados ${ }^{16}$. En segundo lugar, las remesas no promueven el crecimiento económico porque se dedican principalmente al consumo privado de las familias y no a la formación del capital. En tercer lugar, las remesas promueven la sustitución del trabajo por ocio y, en caso de que el trabajo de la mujer esté mal visto en esas sociedades, el endurecimiento de las limitaciones tradicionales a su participación laboral. En cuarto lugar, la cualificación que los migrantes podrían obtener es irreal, pues muchos de ellos se emplean en trabajos que requieren menos cualificación que la que dis-

14 El modelo de Todaro parte de que la migración es fundamentalmente un fenómeno económico, resultado de una decisión perfectamente racional. El emigrante decide en base a las diferencias de ingresos, pero no sobre los ingresos reales, sino sobre los ingresos esperados. Puesto que no se da una economía de pleno empleo, el emigrante hace sus cálculos ponderando la diferencia positiva de renta esperada entre el lugar de origen y el de destino, pero además cuenta con la probabilidad y el riesgo de quedar desempleado o subempleado durante un período de tiempo considerable. De esta manera, las tasas migratorias que superan las tasas de crecimiento de los puestos de trabajo en los lugares de llegada no son sólo posibles, sino racionales, si se tiene en cuenta que la rentabilidad de la emigración se está calculando a largo plazo, a partir de unas situaciones de cualificación y renta que se toman como puntos de partida.

15 Como afirma Sassen, siguiendo las exposiciones de Thomas, «a finales del siglo XIX, hubo algún grupo destacado de economistas políticos que se dedicaba a deliberar el impacto que producía el libre comercio en el movimiento internacional de capital y de trabajo. En el siglo xVIII, la teoría del libre comercio se basaba en la supuesta inmovilidad del factor de producción internacional. La circulación internacional de mercancías se consideraba como un proceso independiente de la movilidad de capital y de trabajo, que sólo se efectuaba dentro de un país. Las transformaciones derivadas del comercio internacional se vieron absorbidas por la movilidad interna del trabajo y del capital, que se desplazaba a través de las clases sociales y de las profesiones. El movimiento de capital y de trabajo de Inglaterra hacia sus territorios de ultramar se veía como parte del proceso de colonización y, al contrario que el libre comercio, requería una regulación estatal» (Sassen, 1993: 17-18). Thomas habría sido de los pocos autores que retoma las hipótesis de los economistas clásicos para reformularlas. A su juicio, los economistas clásicos no vieron la necesidad de examinar el papel del poder en el proceso de intercambio entre el país central y sus países dependientes (Thomas, 1973: 13). Thomas retoma el concepto de "grupos no competitivos» y trata de analizar los flujos de personas y capital desde Europa a EE.UU. tomándolos como una unidad de análisis global. Demuestra que fue precisamente el libre comercio el responsable de la migración del trabajo y del capital, situación que, a la larga, fue beneficiosa para todos.

16 En realidad, afirma, «muchos países en vías de desarrollo están padeciendo el problema actual de la "fuga de cerebros", proceso por el cual doctores, ingenieros y otros profesionales han emigrado a los países industrializados y a los países miembros de la OPED en pos de salarios más altos. Incluso entre los trabajadores industriales, una gran proporción de los emigrantes pueden ser muy cualificados» (Todaro, 1988: 317 ). 
ponen. Por último, tampoco suponen las migraciones una distribución de la renta más equitativa puesto que los flujos migratorios suelen estar constituidos por individuos de renta media. De aquí se deducen importantes consecuencias políticas ${ }^{17}$. El blindaje de fronteras muestra la silueta más sombría de una Europa atemorizada por una posible avalancha de hambrientos y delincuentes que constituirían el grueso de La gran migración, de la que ya hablaba Enzensberger a principios de los noventa (Enzensberger, 1992). Parece que, en la actualidad, las poblaciones europeas empiezan a ser conscientes de que la presencia de migrantes del Sur demanda poner en marcha políticas sociales que faciliten su integración ${ }^{18}$.

Las denominadas políticas de cooperación internacional son, quizá, el mejor fruto que han ofrecido esas perspectivas. Si los vecinos del Sur se dirigen al Norte en busca de recursos, la única manera de controlar esos flujos es invirtiendo en «desarrollo» en esos países, de manera que la gente no «necesite» emigrar y, de paso, dejen de amenazar las políticas de bienestar occidentales, ya de por sí decadentes. A nuestro juicio, estas políticas encuentran sobrada justificación a poco que profundicemos en las causas del desigual reparto de la riqueza en el planeta. Sin embargo, el argumento de que contribuyen a disminuir el volumen de migrantes nos parece más que dudoso.

\section{LAS MIGRACIONES EN TIEMPOS DE GLOBALIZACIÓN}

Sólo en fechas recientes, los investigadores han vuelto a revisar conjuntamente la bibliografía generada en el campo de las migraciones laborales internacionales y la que tiene que ver con la internacionalización de la producción (Sassen, 1993: 31). Se afirma que, en

\footnotetext{
17 Entre ellas, Todaro destaca la necesidad de crear un equilibrio económico apropiado entre las zonas de emigración y las de inmigración, fomentar las industrias a pequeña escala, eliminar las distorsiones en los precios de los factores, elegir las tecnologías adecuadas, internalizar los beneficios de la emigración exterior y modificar la relación directa entre educación y empleo. En lo que se refiere a este último punto, sugiere que «la aparición del fenómeno de los "desempleados cultos" en muchos países en vías de desarrollo ha puesto en tela de juicio la conveniencia de extender masivamente los sistemas educativos, especialmente los niveles más elevados. La educación formal se ha convertido en el túnel selectivo por el que deben pasar todos los que deseen obtener un empleo. Como los puestos de trabajo del sector moderno crecen más lentamente que el número de personas que salen del túnel educativo, se hace necesario alargar el túnel y estrechar la salida (...) Hoy en día, muchos sistemas educativos del Tercer Mundo son una copia de los sistemas occidentales y, por ello, preparan a los estudiantes para trabajar en un pequeño sector moderno que emplea, como mucho, del 20 al 30\% de la población activa. Se descuida así, en gran medida, muchas de las cualificaciones necesarias para el desarrollo» (Todaro, 1988: 324-325).
}

18 Según se desprende de los datos de la encuesta Eurobarómetro, en la actualidad, «por una parte, muchos ciudadanos de la UE favorecen políticas encaminadas a mejorar la coexistencia de mayorías y minorías. El apoyo a estas políticas se ha incrementado en los tres últimos años. Por otra parte, una mayoría de europeos ha manifestado preocupación en relación con las minorías, porque teme que éstas amenacen la paz social y el bienestar social; este porcentaje aumentó a lo largo del período que va de 1997 al 2000. La gente está inquieta sobre el desempleo, la pérdida de bienestar social y la caída de la calidad de la enseñanza. Una minoría de europeos pequeña, pero importante, se siente perturbada personalmente por la existencia de minorías» (Sora, 2000: 7). 
tiempos de globalización, las migraciones internacionales y los movimientos internacionales de capital circulan en sentido inverso, generando cada vez más desigualdades, de donde se deduce una profunda crítica a las teorías del desarrollo porque no se ha producido el equilibrio esperado. Como señala Sassen, refiriéndose a los EE.UU., «los principales países emisores de migración a los Estados Unidos en los quince últimos años, han recibido todos una gran inversión extranjera orientada a la exportación. Podría parecer que este hecho contradice la proposición central en la teoría del desarrollo, a saber, ya que la inversión extranjera crea puestos de trabajo, debería actuar como un freno para la emigración; este freno debería ser particularmente fuerte en países con altos niveles de inversión orientada a la exportación, a causa de su naturaleza de trabajo intensivo» (Sassen, 1993: 35) ${ }^{19}$. La argumentación de Sassen sugiere que son los países desarrollados los responsables de los movimientos migratorios que reciben porque desestabilizan las estructuras sociales de los países en desarrollo y generan expectativas en la población nativa de esos países sobre las posibilidades que tendrían de mejorar su nivel de vida en otro espacio social.

Cada vez parece más obvio que las migraciones internacionales no pueden ser consideradas como una mera adición de conductas individuales, ni responden a un solo factor, ni tienen que ver únicamente con políticas nacionales. En primer lugar, resulta innegable que las conductas migratorias, como otros fenómenos sociales, emergen en un contexto que hace que las personas se sientan coaccionadas, incitadas o seducidas, o las tres cosas al mismo tiempo, por lo que se plantean emigrar ${ }^{20}$.

En segundo lugar, es dudoso que se puedan explicar los movimientos migratorios a partir de un solo factor o una sola causa, ya se tome en cuenta el volumen de población, la pobreza o la demanda de mano de obra por parte de los países de destino del flujo migratorio. Como señalaba Petersen en 1958, «las dificultades económicas, por ejemplo, pueden ser denominadas como causa de la migración sólo si existe una correlación entre dificultades — como quiera que sean definidas - y la propensión a migrar. Generalmente la relación suele darse a la inversa; por ejemplo, la emigración de masas desde Europa en los tiempos modernos se desarrolló al mismo tiempo que el crecimiento en el mercado del nivel de vida europeo. Como se ha observado en numerosos estudios, la correlación se da también en el ciclo de negocios en los países receptores, y siempre esta relación explica las fluctuaciones en la tasa de emigración más que su nivel absoluto. El diferencial de clase en la tasa de emigración no puede ser adscrito a las diferencias económicas. La clase me-

19 La cursiva es nuestra.

20 A este respecto, desde la teoría funcionalista se planteaba el concepto de «deprivación relativa». Los neoclásicos entienden que los individuos llevan a cabo un cálculo de costes-beneficios. Los marxistas no ofrecieron nunca una explicación pues se suponía que en las relaciones el trabajo seguía al capital. 
dia vive en circunstancias más confortables, pero para muchos, moverse hacia América podría significar también una mejora material definitiva. Durante el período de emigración de masas, sin embargo, esto se estereotipó como conducta de clase baja, más o menos poco patriótica para las gentes de bien» (Petersen, 1958: 259)21.

En tercer lugar, debería ser obvio que las migraciones internacionales no tienen que ver únicamente con cuestiones domésticas. Los efectos de las políticas exteriores, de las actuaciones económicas en un determinado país de las empresas transnacionales o de los ciudadanos, así como la historia de las relaciones entre los países o la imagen que se difunde en los medios de comunicación, deben ser también tenidos en cuenta. En esta línea, las políticas migratorias y las leyes de extranjería pueden ser entendidas como posicionamientos gubernamentales respecto a las poblaciones de terceros países. Pero ése es sólo un aspecto de la intervención estatal, pues otras actuaciones tienen que ver con las condiciones en las que entidades públicas o privadas pueden movilizar mercancías, capitales, beneficios e información de un país a otro. Como señalan los economistas, la inversión directa en terceros países es «el vehículo más intenso y duradero de la inserción de un país en la economía global»22. Constituye un buen indicador de una globalización económica que se caracteriza por ser claramente desigual ${ }^{23}$.

Tanto la hipótesis de Sassen como la de los economistas pueden contrastarse empíricamente. Por ejemplo, si nos referimos a España, se puede ver cómo la inserción de España en la economía global tomó como punto de partida la «Nueva ordenación económica» proclamada por el gobierno franquista en 1959, pues es entonces cuando abiertamente se decide potenciar la inversión directa extranjera en nuestro país, inversión que no se hizo esperar ${ }^{24}$. Al mismo tiempo, y si se observa el número de emigrantes que salieron de España en esos años, puede corroborarse que es en el período 1956-1975 cuando mayor número de personas abandonaron nuestro país ${ }^{25}$. Sin embargo, no es ese el período en el que pre-

\footnotetext{
21 La traducción es nuestra.
}

22 Así se señala en la Introducción Editorial de la revista Papeles de Economía Española, n. ${ }^{\circ}$ 66, en su monográfico sobre España ante la economía global (1996: IX).

${ }^{23}$ Como señala Aristide R. Zolberg, «las fronteras internacionales sirven para mantener la desigualdad global» (Zolberg, 1989: 406). La traducción es nuestra.

24 Como señalaba Juan R. Cuadrado, en un análisis sobre las inversiones extranjeras directas en España, realizado en 1975, dichas inversiones superaron los 20 millones de dólares anuales desde 1959 hasta 1974, destacando los años de 1960 , en el que se recibieron 90 millones de dólares; los años 1965 y 1966, en los que se superaron los 35 millones de dólares, y el año 1973, en el que se recibieron 40 millones de dólares de inversión extranjera (Cuadrado, 1975: 26-27).

25 Como se detalla en el Anuario de Migraciones, durante el período de 1946 a 1955 se contabilizaron 570.164 emigrantes. En el período que va desde 1956 a 1965 se contabilizaron 788.823 emigrantes. Desde 1966 a 1975 emigraron 812.319 personas, descendiendo el número en el siguiente período, que abarca desde 1976 a 1985, hasta 196.246 emigrantes. La mayor parte de los emigrantes tuvieron su destino en Europa y América. 
tendemos focalizar la atención. Nos centraremos en el cambio de España de «país de emigración» a «país de inmigración».

\section{EL PROCESO DE GLOBALIZACIÓN DE LA ECONOMÍA ESPAÑOLA Y LA CONVERSIÓN DE ESPAÑA EN PAÍS DE INMIGRACIÓN}

España ingresó en la Unión Europea en 1986. Un año antes se había promulgado la primera Ley de Extranjería. Desde nuestro punto de vista, los sociólogos no han resaltado suficientemente la posible relación entre ambos acontecimientos. Se dice a menudo que hemos pasado de ser un país de emigración a ser un país de inmigración, presunto fenómeno que los datos no apoyan suficientemente ${ }^{26}$, por lo que ese cambio podría formularse de otro modo. A mediados de los ochenta, cuando en España se está viviendo una época de crecimiento económico, se produce el ingreso en la Comunidad Europea, que, a su vez, se apoya con una política de control de las poblaciones que proceden de los países en vías de desarrollo. El «despegue» de España como «país de inmigración» se produce ya en los años noventa, lo mismo que el crecimiento de la inversión directa española en el extranjero.

Como se puede observar en la tabla 1, el volumen de transacciones de España con los países desarrollados es mayor que el que se lleva con los países en vías de desarrollo, por lo que es posible que todavía sigamos siendo un «país de emigración». Las importaciones sobrepasan a las exportaciones si hablamos de la relación de España con los países más desarrollados con los que, a su vez, intercambiamos más población. Si nos referimos a los países en vías de desarrollo, las importaciones también sobrepasan las exportaciones, aunque se produce un volumen menor. Pero, si descontamos el caso de Argentina, son pocos los españoles residentes en esos países. El grueso de la inversión total española en el extranjero todavía sigue dirigiéndose principalmente a los países desarrollados, lugares con los que, hoy por hoy, se produce un mayor tráfico de población y de capitales.

En las tablas 2 y 3 presentamos la matriz de correlaciones bivariadas a partir de los datos de la anterior. A primera vista, se puede observar que los niveles de correlación son mucho más altos entre las variables que se refieren a los países desarrollados que las variables que relacionan a España con los países en desarrollo, lo que habría que interpretar diciendo que España mantiene una relación más consolidada con los países desarrollados que con los países en desarrollo.

26 Si se tienen en cuenta los datos del Anuario de Migraciones, durante el año 1999 había 1.571 .941 españoles residiendo en el extranjero, mientras que residían en España 801. 329 extranjeros. De los españoles residentes en el extranjero, 672.420 correspondían a Europa, 12.937 a África, 8.911 a Asia y 863.465 a América. El saldo migratorio español (emigración menos retorno) viene siendo negativo ininterrumpidamente desde 1986, pasando de -603 personas en 1986 a -34.570 en 1999 . 
TABLA 1

Principales nacionalidades de origen con más de 10.000 residentes en España según la relación que España mantiene con sus países de origen (1998)

\begin{tabular}{|c|c|c|c|c|c|c|}
\hline & & $\begin{array}{r}\text { Extranjeros } \\
\text { residentes } \\
\text { en España } \\
\text { por país } \\
\text { de origen }\end{array}$ & $\begin{array}{r}\text { Españoles } \\
\text { residentes en } \\
\text { el extranjero } \\
\text { por país } \\
\text { de destino }\end{array}$ & $\begin{array}{r}\text { Importaciones } \\
\text { (millones } \\
\text { de pesetas) }\end{array}$ & $\begin{array}{r}\text { Exportaciones } \\
\text { (millones } \\
\text { de pesetas) }\end{array}$ & $\begin{array}{r}\text { Inversión total } \\
\text { española en } \\
\text { estos países } \\
\text { (millones } \\
\text { de pesetas) }\end{array}$ \\
\hline & Gran Bretaña & 76.402 & 45.930 & 1.481 .690 & 1.374 .183 & 102.327 \\
\hline & Alemania & 60.828 & 140.313 & 3.058 .289 & 2.220 .374 & 185.673 \\
\hline & Portugal & 44.038 & 10.516 & 555.182 & 1.518 .786 & 93.749 \\
\hline & Francia & 43.265 & 273.181 & 3.616 .143 & 3.189 .550 & 40.328 \\
\hline & Italia & 29.871 & 15.995 & 1.933 .110 & 1.518 .985 & 28.044 \\
\hline & Holanda & 17.243 & 18.667 & 849.283 & 560.518 & 156.503 \\
\hline & EE.UU. & 15.649 & 100.111 & 1.163 .510 & 678.338 & 56.769 \\
\hline & Bélgica & 13.055 & 50.576 & 676.238 & 454.778 & 99.247 \\
\hline Tot & $1-8$ & 300.351 & 655.289 & 13.333 .445 & 11.515 .512 & 762.640 \\
\hline & Marruecos & 161.870 & 6.257 & 112.116 & 157.151 & 3.414 \\
\hline & Perú & 27.263 & 24.641 & 25.855 & 32474 & 10.025 \\
\hline & R. Dominicana & 26.854 & 17.016 & 4.045 & 28.801 & 710 \\
\hline & Cuba & 16.556 & 16.012 & 19.975 & 81.817 & 246 \\
\hline & Argentina & 16.290 & 298.798 & 138.406 & 187.491 & 28.981 \\
\hline & Filipinas & 13.765 & 2.244 & 18.800 & 18.102 & 1.239 \\
\hline 15. & Colombia & 13.627 & 34.961 & 26.730 & 67.818 & 62.609 \\
\hline & Ecuador & 12.933 & 5.698 & 24.655 & 14.113 & 10.036 \\
\hline 17. & China & 24.693 & 594 & 487.357 & 73.194 & 999 \\
\hline \multicolumn{2}{|c|}{ Total 9-17 } & 313.851 & 406.221 & 857.939 & 660.961 & 118.259 \\
\hline \multicolumn{2}{|c|}{ Total } & 801.329 & 1.995 .192 & 19.838 .001 & 16.289 .587 & 1.997 .925 \\
\hline
\end{tabular}

FUENTES:

Elaboración propia. Anuario Estadístico de Extranjería, 1999, Ministerio de Asuntos Exteriores, 1988; Anuario de Migraciones, 1998, Ministerio de Economía, Dirección General de Comercio e Inversiones, 1999.

En lo que se refiere a la relación de España con los países desarrollados, las importaciones a esos países aumentan a medida en que aumenta el volumen de exportaciones, llegando a alcanzar el índice de correlación un valor de 0,887. Si seguimos observando, se puede notar también que importaciones y residentes españoles en el extranjero también correlacionan fuertemente, llegando a alcanzar un valor de 0,840 , al igual que exportaciones y residentes españoles, variables que llegan a alcanzar un índice de 0,766. Dicho en dos palabras, a más residentes españoles en países desarrollados, más intercambio económico (importaciones y exportaciones) con esos países. 
TABLA 2

Relación de España con los países desarrollados. Matriz de correlaciones bivariadas. Correlación de Pearson ( $\mathrm{N}=$ Gran Bretaña, Alemania, Portugal, Francia, Italia, Holanda, EE.UU., Bélgica)

\begin{tabular}{|c|c|c|c|c|c|}
\hline & $\begin{array}{r}\text { Extranjeros } \\
\text { residentes } \\
\text { en España }\end{array}$ & $\begin{array}{r}\text { Españoles } \\
\text { residentes } \\
\text { en el } \\
\text { extranjero }\end{array}$ & $\begin{array}{r}\text { Importa- } \\
\text { ciones } \\
\text { (millones } \\
\text { de pesetas) }\end{array}$ & $\begin{array}{r}\text { Exporta- } \\
\text { ciones } \\
\text { (millones } \\
\text { de pesetas) }\end{array}$ & $\begin{array}{r}\text { en est } \\
\text { país } \\
\text { (millon } \\
\text { de peseta }\end{array}$ \\
\hline Extranjeros residentes en España & 1,000 & 0,192 & 0,435 & 0,566 & 0,2 \\
\hline Españoles residentes en el extranjero & 0,192 & 1,000 & $0,840^{\star *}$ & 0,766 & $-0,1$ \\
\hline Importaciones (millones de pesetas) & 0,435 & $0,840^{\star *}$ & 1,000 & $0,887^{\star *}$ & $-0,07$ \\
\hline Exportaciones (millones de pesetas) & 0,566 & $0,766^{*}$ & $0,887^{\star *}$ & 1,000 & $-0,1$ \\
\hline Inversión total española en estos paíse & 0236 & -0.164 & -0.077 & -0169 & 10 \\
\hline
\end{tabular}

TABLA 3

Relación de España con los países en desarrollo. Matriz de correlaciones bivariadas. Correlación de Pearson ( $N$ = Marruecos, Perú, R. Dominicana, Cuba, Argentina, Filipinas, Colombia, Ecuador, China)

Extranjeros residentes en España

\begin{tabular}{|c|c|c|c|c|}
\hline $\begin{array}{l}\text { tranjeros } \\
\text { esidentes } \\
\text { España }\end{array}$ & $\begin{array}{r}\text { Españoles } \\
\text { residentes } \\
\text { en el } \\
\text { extranjero }\end{array}$ & $\begin{array}{r}\text { Importa- } \\
\text { ciones } \\
\text { (millones } \\
\text { de pesetas) }\end{array}$ & $\begin{array}{r}\text { Exporta- } \\
\text { ciones } \\
\text { (millones } \\
\text { de pesetas) }\end{array}$ & $\begin{array}{r}\text { Inversión } \\
\text { total } \\
\text { española } \\
\text { en estos } \\
\text { países } \\
\text { (millones } \\
\text { de pesetas) }\end{array}$ \\
\hline 1,000 & $-0,171$ & 0,078 & 0,491 & $-0,224$ \\
\hline$-0,171$ & 1,000 & 0,049 & $0,684^{*}$ & 0,369 \\
\hline 0,078 & 0,049 & 1,000 & 0,281 & $-0,164$ \\
\hline 0,491 & $0,684^{*}$ & 0,281 & 1,000 & 0,209 \\
\hline$-0,224$ & 0,369 & $-0,164$ & 0,209 & 1,000 \\
\hline
\end{tabular}

\footnotetext{
* La correlación es significante al nivel 0,05 (bilateral).
} 
Sin embargo, si nos fijamos un poco más podemos notar que los residentes extranjeros que provienen de países desarrollados no parecen moverse tan al unísono con mercancías y capitales como los españoles residentes en esos países, pues el mayor índice de correlación se da entre los residentes extranjeros y países donde España exporta más $(0,566)$. Las inversiones sólo correlacionan positivamente, aunque de una manera muy débil, con los residentes extranjeros en España $(0,236)^{27}$.

Antes dijimos que el tipo de intercambios de personas, mercancías y capitales entre España y los países en desarrollo está mucho menos consolidado. El valor más alto del índice de correlación lo encontramos en este caso entre las variables exportaciones y residentes españoles en esos países, llegando a alcanzar un valor de 0,684. Sin embargo, en este caso los residentes españoles en el extranjero prácticamente no correlacionan con los países en los que España importa. La correlación entre el volumen de españoles en esos países e inversión total, sin ser todavía significativa, llega a alcanzar un valor de 0,369.

En todo caso, hay que anotar que estamos hablando de inversión total y no de inversión directa en el extranjero ${ }^{28}$. En lo que se refiere a la inversión total, los economistas españoles confirmaban en 1996 que, también en el caso español, «las inversiones en busca de objetivos estratégicos se dirigen a países de alta renta per cápita y gran cantidad de activos creados (...). Las inversiones en busca de factores de producción van destinadas a países, con activos naturales abundantes, con los que España tiene relativamente pocas relaciones comerciales, pero que son también el destino de inversiones directas de otros países» (Campa y Guillén, 1996: 245). A eso habría que añadir que si nos referimos a los países desarrollados, las inversiones se dirigen a aquellos lugares donde hay menos residentes españoles; mientras que si hablamos de los países en desarrollo, las inversiones y los residentes españoles caminan al unísono.

Según la teoría ecléctica (Dunning, 1988), si nos detenemos en las actividades de inversión directa en el extranjero, observaremos que se encuentran íntimamente ligadas al nivel de desarrollo de los países. A un mayor desarrollo corresponde un mayor volumen de inversión directa en el extranjero. Como se puede observar en la tabla 4, el volumen de in-

27 Hay que tener en cuenta que estamos hablando de inversiones totales, y no de inversiones directas en el extranjero.

28 Como señala Enrique Palazuelos, en el libro que lleva por título La globalización financiera, «el paisaje de las relaciones financieras internacionales presenta un carácter ambivalente. De un lado, es cierto que en los mercados financieros intervienen numerosos actores que pertenecen a múltiples países, que realizan infinitas operaciones y utilizan muchas monedas, que intercambian un sinfín de instrumentos y que entablan una intensa competencia. Pero, de otro lado, el examen de cuanto ocurre en el interior de esas relaciones financieras pone al descubierto que, simultáneamente con esa diversidad, en esos mercados existe una notable concentración que se manifiesta en el hecho de que el grueso mayoritario de la actividad financiera se lleva a cabo entre un número reducido de países, de monedas y de agentes económicos» (Palazuelos, 1998: 133). 
versiones del extranjero en España y de España en el extranjero ha aumentado significativamente en la década de los noventa. En ese proceso, a medida que España se ha ido constituyendo como país de inmigración en el seno de la Unión Europea, se ha ido convirtiendo también en propulsor de inversiones directas en el extranjero y, en términos relativos, va dejando de ser un país receptor de inversión extrajera directa ${ }^{29}$.

TABLA 4

Inversiones directas del extranjero en España y de España en el extranjero

(millones de pesetas)

\begin{tabular}{lrr} 
Año & $\begin{array}{r}\text { Inversiones directas que proceden } \\
\text { del extranjero }\end{array}$ & $\begin{array}{r}\text { Inversiones directas de España } \\
\text { en el extranjero }\end{array}$ \\
\hline 1993 & 68430 & 20533 \\
1994 & 76087 & 23795 \\
1995 & 79133 & 26444 \\
1996 & 84434 & 31.452 \\
1997 & 89824 & 44355 \\
1998 & 100023 & 59126 \\
1999 & 114883 & 109797 \\
2000 & 153322 & 175072 \\
$2001^{*}$ & 169469 & 200408
\end{tabular}

* Los datos del 2001 se refieren sólo hasta el segundo cuatrimestre.

FUENTE:

Banco de España, Indicadores económicos.

Lo que no explicaba la teoría ecléctica era la relación que se establece entre los flujos migratorios y la inversión directa, cosa de la que sí se ocupó Saskia Sassen. Para el caso de EE.UU., esta autora resaltaba la correlación entre la presencia de poblaciones procedentes del extranjero, particularmente de países en vías de desarrollo, y la realización de inversiones estadounidenses directas en esos países ${ }^{30}$. A continuación observaremos cómo la cre-

29 Es de destacar cómo la entrada de inversión extranjera directa intracomunitaria se ha reducido en el caso español en el período que va desde 1992 a 1997. Según los datos de EUROSTAT y de la Comisión Europea, mientras que esa inversión suponía un 1,1\% del PIB en 1992, en 1997 suponía un 0,6\%. La media de ese período era para el caso español de un 0,9\%, siendo la media europea del mismo período de un $1,9 \%$.

30 Según los datos que maneja Sassen, «la inversión directa global (a partir de ahora, IED) para los principales países en vías de desarrollo, aumentó de 35.000 millones de dólares en 1967 a 76.000 millones de dólares en 1976 (ILO, 1981: 2.5). La posición de la IED de Alemania Occidental, fue de 1,9 mil millones de dólares en 1970, a 5,9 mil millones en 1976; la de los Países Bajos de 2,2 miles de millones de dólares a 3,5 miles de millones; la de Francia, de 3,8 miles de millones a 5,2 miles de millones; y la del Reino Unido de 5,3 miles de millones. En el caso de los Estados Unidos, aumentó de 22.000 millones en 1970 , a 40.000 en 1976» (Sassen, 1993: 149-151). 
ciente llegada de personas de países en vías de desarrollo discurre en paralelo al aumento de llegada de inversión directa española en esos países. Nos detendremos a examinar el caso de España y Marruecos ${ }^{31}$.

\section{UN EJEMPLO DEL PROCESO DE GLOBALIZACIÓN: INVERSIONES Y FLUJOS MIGRATORIOS ENTRE ESPAÑA Y MARRUECOS}

Las relaciones entre España y Marruecos, tanto las económicas como las que se refieren al asentamiento de personas, estuvieron suspendidas durante mucho tiempo. Se reinician tras la muerte de Franco, cuando el gobierno entrega el Sahara Occidental a Marruecos y Mauritania. A partir de ahí se produce un progresivo acercamiento que culmina con el viaje del rey Juan Carlos a Marruecos en 1979, el viaje del rey Hasán II a Palma de Mallorca para entrevistarse con el rey español en 1982, y la visita oficial de Hasán II a España en 1989. Como se puede observar en la tabla 5 , tanto en los aspectos económicos como en los que se refieren a las poblaciones migrantes, a partir de la transición política española, y sobre todo durante la década de los noventa, se ha desarrollado todo un marco de relaciones que ha culminado en el establecimiento de contactos institucionales, tratados, acuerdos y desarrollos normativos a través de los cuales se canalizan tanto las inversiones como el movimiento de personas.

Como vemos en la tabla 5, España y Marruecos han desarrollado relaciones, tanto en lo que se refiere a las económicas como a las que tienen que ver con las poblaciones migrantes, que van mucho más allá de los asuntos relacionados con Ceuta, Melilla y la pesca, que constituían los ejes en torno a los que giraban las relaciones anteriores.

En primer lugar, se pueden notar las consecuencias de la política económica liberalizadora que los gobiernos marroquíes desarrollaron desde los años ochenta, siguiendo las consignas del FMl y el Banco Mundial, que les llevó a globalizar su economía ${ }^{32}$. Esa política económica supuso una apertura a las inversiones extranjeras, a las que se acudía con el fin de equilibrar la Balanza de Pagos. El déficit de la Balanza de Pagos, desde los años ochenta,

\footnotetext{
31 Hemos elegido este caso porque en los últimos meses las relaciones entre España y Marruecos están generando una polémica considerable en distintos sectores y partidos políticos, polémica que está poniendo sobre la mesa diferentes opiniones sobre el lugar que España tiene y debe tener en el contexto internacional. En todo caso, somos conscientes de que este análisis es posible que se pueda corroborar de una manera mucho más contundente con países de América Latina como Perú.

32 Como señala Gowan, «la necesidad de un sistema financiero internacional, en sí misma, no es algo que se derive del capitalismo. Surge de la realidad política y económica de un mundo dividido en Estados independientes que poseen distintas monedas y de la existencia de grupos dentro de cada Estado que desean hacer negocios con otros Estados y en el interior de estos últimos» (Gowan, 2000: 33).
} 
TABLA 5

\section{Marco normativo de las relaciones entre España y Marruecos}

1977 - Acuerdo de pesca. Marruecos insistirá tras el acuerdo en que España aumente sus contrapartidas en cooperación técnica, cultural, económica, médica y educacional. nacionalidad prevalece el lus soli para la tercera generación si al menos uno de los padres ha nacido en España.

1983 - Nuevo acuerdo de pesca. España se obligaba a
reducir en un $40 \%$ su esfuerzo pesquero en aguas
marroquíes en cuatro años y a conceder una ayu-
da financiera de 550 millones de dólares en crédi-
tos comerciales de Estado a Estado, y con cargo
al Fondo de Ayuda al Desarrollo (FAD).
- 3 de marzo: Anuncio oficial de que España parti-
ciparía, a través del fomento del comercio exterior,
y con un grupo japonés, en la construcción de una
planta de ácido sulfúrico valorada en 200 millones
de dólares (la participación era de un $33 \%$ ).

- Contactos institucionales que sientan las bases de lo que fue la Operación Tránsito (desde 1990, Operación Paso del Estrecho).

1985 - Ley de Extranjería.

1986 - Ingreso de España en la Unión Europea.

1988 - Nuevo acuerdo pesquero (firmado por la Comunidad Europea).

- Crédito financiero concedido por España por valor de 1.000 millones de dólares para permitir la implantación en Marruecos de hombres de negocios e industriales españoles.
- Reunión de la Comisión Mixta Consular (creada en 1987) en la que se trata el tema de los ciudadanos marroquíes que viven en España, junto con los de la Operación Tránsito, Seguridad Social, tráfico de drogas y establecimiento de visados.
1989 - Acuerdo entre España y Marruecos para promoción y protección mutua de inversiones.
- Acuerdos sobre cooperación militar entre España y Marruecos.

- Adhesión de España a los acuerdos de Schengen.

- Instauración de visados para la entrada a España de ciudadanos magrebíes.

- Firma por los soberanos del Tratado de Amistad, Buena Vecindad y Cooperación Hispano-Marroquí.

- Proceso de Regularización de junio a diciembre. 
TABLA 5

\section{Continuación}

Año

Marco normativo referente

a las relaciones económicas
Marco normativo referente a migraciones
1992
- Acuerdo entre España y Marruecos. Marruecos se compromete a readmitir todos los extranjeros (salvo los ciudadanos de los países de la Unión del Magreb Árabe) que hayan entrado ilegalmente por sus fronteras.

- Entrada en vigor de los acuerdos de Schengen de 1990.

\begin{tabular}{|c|c|c|}
\hline 1996 & $\begin{array}{l}\text { - Aprobación en Marruecos de la Carta de inversio- } \\
\text { nes. } \\
\text { - Acuerdo bilateral que pone en marcha un meca- } \\
\text { nismo de conversión de deuda marroquí en inver- } \\
\text { siones, por un montante de } 6.250 \text { millones de pe- } \\
\text { setas. }\end{array}$ & $\begin{array}{l}\text { - Asociación Marruecos-UE (entró en vigor } \\
\text { el } 1 \text { de marzo de 2000). }\end{array}$ \\
\hline 1997 & $\begin{array}{l}\text { - Renovación del acuerdo bilateral de } 1996 \text { por un } \\
\text { montante de } 4.625 \text { millones de pesetas. }\end{array}$ & $\begin{array}{l}\text { - Los servicios de seguridad marroquíes } \\
\text { proceden a la detención de } 13.184 \text { per- } \\
\text { sonas aprehendidas cuando intentan } \\
\text { emigran clandestinamente a la UE. }\end{array}$ \\
\hline 1998 & $\begin{array}{l}\text { - En Marruecos: Régimen para las inversiones ex- } \\
\text { tranjeras que suprime la autorización previa de la } \\
\text { Oficina de Cambio. Se introduce la libertad de ce- } \\
\text { sión de inversiones entre extranjeros y se estable- } \\
\text { ce la automaticidad de las transferencias de los } \\
\text { beneficios. }\end{array}$ & $\begin{array}{l}\text { - Creación en la UE del Grupo de Alto Ni- } \\
\text { vel Asilo Migración (centrado en los pro- } \\
\text { blemas de seguridad). } \\
\text { - Marruecos participa como miembro ob- } \\
\text { servador del Grupo TREVI, denominado } \\
\text { después K4. }\end{array}$ \\
\hline
\end{tabular}

- Cumbre de Tampere. Plan de acción especial para Marruecos, coordinado por España, que refuerza el enfoque de seguridad en lo relativo a la emigración/inmigración.

- Decisión del gobierno español de invertir 25.000 millones de pesetas para blindar la frontera sur y evitar la migración clandestina.

- 780 pateras interceptadas y 14.893 detenciones practicadas.

- Acuerdo bilateral entre España y Marruecos en materia de mano de obra.

FUENTES:

Del Pino (1990), López Barnabé (1993), Moreno Fuentes (2001), Martínez-Caro de la Concha (2001), Benguelduz (2002). 
se intenta paliar también mediante las divisas que aporta el turismo y las remesas de los emigrantes marroquíes en el extranjero ${ }^{33}$, remesas que, en la actualidad, todavía suponen una importante fuente de ingresos para la economía marroquí34 y que se destinan principalmente a la compra de un alojamiento en el sector urbano inmobiliario, tal y como se venía haciendo desde los años ochenta (Chevassu, 1990: 204) ${ }^{35}$.

En segundo lugar, desde que en 1986 España ingresa en la Unión Europea, las relaciones hispano-marroquíes se desarrollan en el marco de la denominada «Fortaleza Europa»36. En lo que se refiere al tema de la inmigración, ésta «no se convierte en motivo diplomático hasta bien entrados los años ochenta. Si bien desde comienzos de la década se habían producido peticiones oficiales marroquíes para tratar de legalizar la situación de los inmigrantes marroquíes, no existía un seguimiento continuado de la cuestión» (López, 1993: 60).

La nueva posición internacional de España justifica que cuando, en 1996, Antonio Izquierdo escribió su libro sobre la inmigración marroquí, lo denominara La inmigración inespera$d a$, título que se corresponde plenamente con los datos que el autor aporta sobre la población extranjera total con permisos de residencia y la procedencia de países del norte de África hasta el año 1994, que aquí reproducimos en la tabla 6 para el caso de Maruecos, ampliando los datos hasta el año 2000.

33 Las transferencias de los inmigrantes marroquíes en España hacia su país de origen son difíciles de registrar y cuantificar. En el estudio más reciente que se ha publicado en España (Bacaría, 1998) se presentan distintas estimaciones. Basándose en los datos del Banco de España, se indica que para el año 1992 el total de transferencias de los emigrantes marroquíes a su país de origen ascendía a 3.210,5 millones de pesetas. Si se tienen en cuenta los datos de otros estudios, y los que se refieren a los giros postales de los inmigrantes, Bacaría estima que, para ese mismo año, pudieron transferirse a Marruecos un mínimo de 9.450,18 millones de pesetas y un máximo de 47.250,90 millones de pesetas (Bacaría, 1998: 77).

34 Basándose en los datos de la Oficina de Cambio marroquí, se estima que «el $90 \%$ de las remesas de los emigrantes marroquíes provienen de los establecidos en Europa. El envío de dinero de marroquíes residentes en el extranjero significa el principal concepto de la balanza de pagos, por delante de los fosfatos y el turismo. Su volumen ha superado los 21.000 millones de dirhams en 2000, es decir, una cifra equivalente a un tercio del montante global de las exportaciones de mercancías o el doble del volumen de las inversiones directas procedentes del exterior en Marruecos. Respecto a las transferencias hacia Marruecos procedentes de España, su montante ha sido para ese año de 886,4 millones de dirhams, es decir, el 3,9\% del total de transferencias realizadas por los marroquíes establecidos en el extranjero. Para hacerse una idea de la importancia económica y financiera de las remesas monetarias, precisemos que el ahorro bancario en Marruecos de los marroquíes residentes en el extranjero supera los 50.000 millones de dirhams en 2000 , es decir, el $40 \%$ del volumen total de depósitos a la vista y a plazo del sistema bancario marroquí» (Belguendouz, 2002: 37).

35 Según Gildas Simon, los fondos ligados a las migraciones internacionales se invierten en el medio urbano, y en primer lugar en el sector inmobiliario. En segundo y tercer lugar tendríamos la inversión en subsistencia de las familias y entretenimiento (Simon, 1990: 11).

36 La idea de «Fortaleza» se ha venido acuñando para describir el impacto que ha tenido la puesta en marcha del Mercado Único de la Unión Europea para las poblaciones residentes que procedían de países del denominado Tercer Mundo, estimadas en unos 15 millones de personas (Kofman y Sales, 1992: 29). 
TABLA 6

España: Total de población extranjera y marroquí con permiso de residencia en España (1966-2001)

\begin{tabular}{|c|c|c|c|c|c|}
\hline Año & Total & Marruecos & Año & Total & Marruecos \\
\hline 1966 & 110.301 & 826 & 1984 & 226.289 & 5.172 \\
\hline 1967 & 122.863 & 993 & 1985 & 241.971 & 5.817 \\
\hline 1968 & 130.744 & 1.188 & 1986 & 293.208 & 8.638 \\
\hline 1969 & 139.347 & 1.472 & 1987 & 334.933 & 11.152 \\
\hline 1970 & 148.400 & 1.710 & 1988 & 380.032 & 11.596 \\
\hline 1971 & 154.874 & 1.860 & 1989 & 249.559 & 14.471 \\
\hline 1972 & 159.122 & 1.960 & 1990 & 278.796 & 16.665 \\
\hline 1973 & 164.068 & 2.198 & 1991 & 360.655 & 49.513 \\
\hline 1974 & 166.067 & 2.308 & 1992 & 393.100 & 54.105 \\
\hline 1975 & 165.039 & 2.277 & 1993 & 430.422 & 61.303 \\
\hline 1976 & 159.249 & 2.146 & 1994 & 461.364 & 63.939 \\
\hline 1977 & 161.761 & 2.150 & 1995 & 499.772 & 74.886 \\
\hline 1978 & 158.207 & 2.072 & 1996 & 538.981 & 77.189 \\
\hline 1979 & 173.582 & 2.628 & 1997 & 609.813 & 111.100 \\
\hline 1980 & 183.264 & 2.964 & 1998 & 719.647 & 140.896 \\
\hline 1981 & 197.870 & 3.596 & 1999 & 801.329 & 161.870 \\
\hline 1982 & 200.743 & 3.765 & 2000 & 895.720 & 199782 \\
\hline 1983 & 210.177 & 4.139 & & & \\
\hline
\end{tabular}

FUENTE:

Elaboración propia a partir de los datos de Izquierdo (1996: 21) y Anuarios de Migraciones (INE).

La interpretación que Izquierdo hace de $\operatorname{los}_{\text {datos }}{ }^{37}$ reza del siguiente modo: «cuando se emprende, durante la segunda mitad de 1991, un masivo proceso de regularización, las comunidades marroquíes y argelina ven cómo sus efectivos se triplican de un modo generoso. Ahí empezaría en mi opinión una nueva fase con rasgos propios y que se va a caracterizar por un progresivo equilibrio en la dualidad (urbano y rural, varones y mujeres, solteros y casados, semi-analfabetos y con estudios) y por la instalación de familias y la lenta difusión de matrimonios. La atención, por tanto, debemos concentrarla únicamente en el último lustro (1990-1994) y más en particular cabe detenerse en el análisis de las regularizaciones de los indocumentados para ver cómo en el ámbito de las migraciones exteriores la política se ha impuesto a la economía» (Izquierdo, 1996: 20). Tras este pasaje, Izquierdo pasa a analizar lo que está ocurriendo en el mercado de trabajo español, resaltando la crisis económica y la destrucción de empleo, para caracterizar después los sectores laborales en los que se insertan los inmigrantes marroquíes.

\footnotetext{
37 Hay que tener en cuenta que Izquierdo estaba analizando los datos hasta 1994.
} 
Ahora nos gustaría invitar al lector a volver la mirada hacia los datos sobre el proceso de inserción de Marruecos en la «globalización económica», en los que quizá podemos encontrar alguna clave más de por qué ha aumentado tanto el volumen de población marroquí en España. Como se puede observar en la tabla 7, en Marruecos las inversiones directas procedentes del extranjero han aumentado considerablemente durante los años noventa.

El hecho de que Marruecos esté internacionalizando su economía no tendría por qué significar que España participara en ese proceso, pero sí lo ha hecho. Se ha pasado de invertir 18,68 millones de dólares en 1990 a 56,56 millones en el año $2000^{38}$. De manera que al tiempo que crecía la migración de trabajadores hacia España, aumentaba también la inversión directa española en Marruecos.

Si se desagregan esas cantidades por sectores económicos, vemos que España ha pasado de invertir principalmente en el sector industrial ${ }^{39}$, particularmente en el textil, a hacerlo en la banca y, a finales del decenio, en las telecomunicaciones, como se puede observar en la tabla 8.

Estas inversiones directas españolas en Marruecos es probable que estén contribuyendo a una mayor desigualdad entre ambos países ${ }^{40}$, pues en los países en desarrollo el proceso de mundialización de su economía conlleva una mayor centralización y homogeneización de los procesos productivos, los cuales se definen y articulan sin tener en cuenta sus intereses nacionales. En este sentido, se puede afirmar que «la homogeneización del espacio económico internacional induce a una jerarquización de los actores estatales en un nuevo sistema internacional. Esto tiene un efecto considerable en la permeabilidad de los Estados a la dinámica global y sobre su capacidad de respuesta: cuanto más periférico es un Estado en esta jerar-

38 España, que en 1994 ocupaba el sexto lugar como inversor extranjero, pasó al tercer puesto en 1998. En 1998, los sectores económicos en los que se estaba ubicando la inversión extranjera eran principalmente el sector industrial y el sector de la banca.

39 Como señalaba Domingo del Pino en 1990: «Instaladas en Marruecos desde la época del Protectorado o poco posterior a él se encuentran las empresas Papeleras de Tetuán, que pertenece a la familia Benet, los Cementos marroquíes de Tetuán, propiedad en un 50 por ciento de Arturo Fierro, Aglorex, de un grupo catalán, Compañía de Lukus, y la Unión Bancaria Hispano, Central; Banesto y Vizcaya. Existen además más de 25 sociedades mixtas para la pesca de altura, principalmente con los grupos marroquíes Baraka, Sentissi, Zniber, Mymbh, Buanani, etc. Setenta y seis empresas españolas estaban establecidas en Marruecos en 1987, de las cuales 13 con una participación de capital español del 100 por ciento» (Del Pino, 1990: 257).

40 Como señala Joaquín Fernández Leiceaga, «lo que diferencia la acción de las filiales en las economías desarrolladas y en las periféricas es que la probabilidad de que aparezcan los efectos positivos es muy superior en las primeras. En las periféricas, la capacidad de inducción de nuevas actividades es baja mientras que el potencial de destrucción de las filiales es más elevado» (Fernández Leiceaga, 1998: 121). 


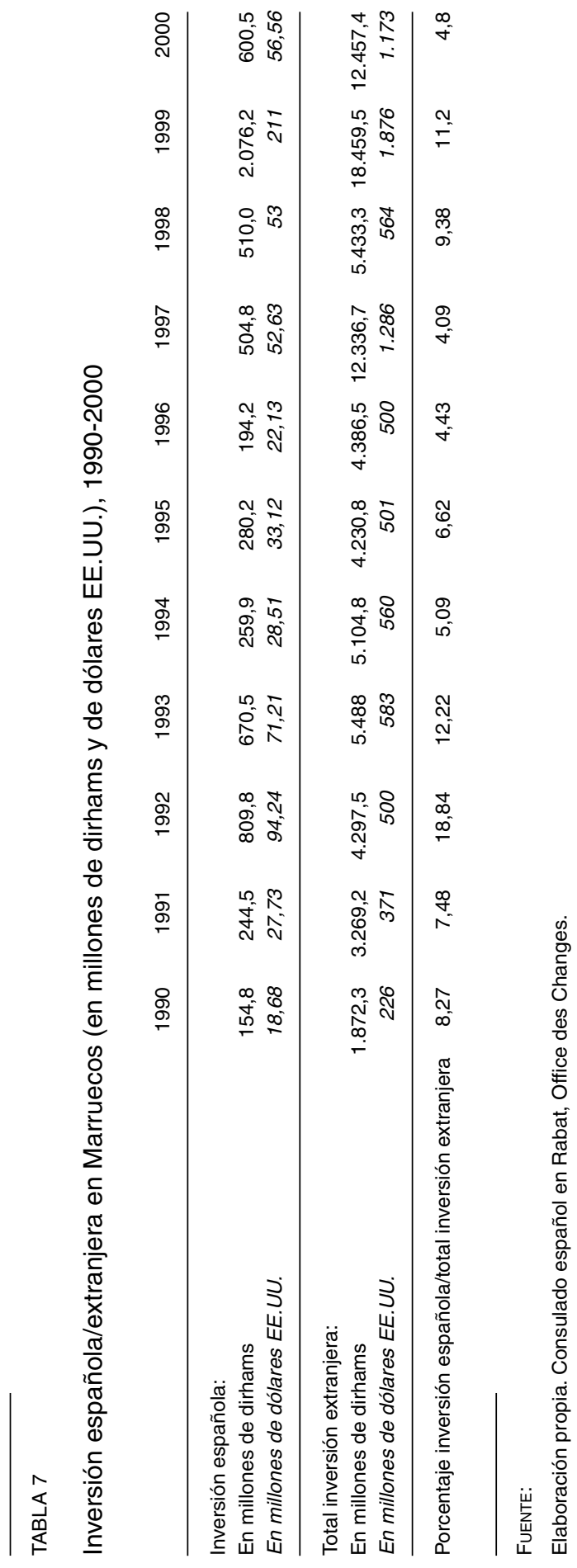




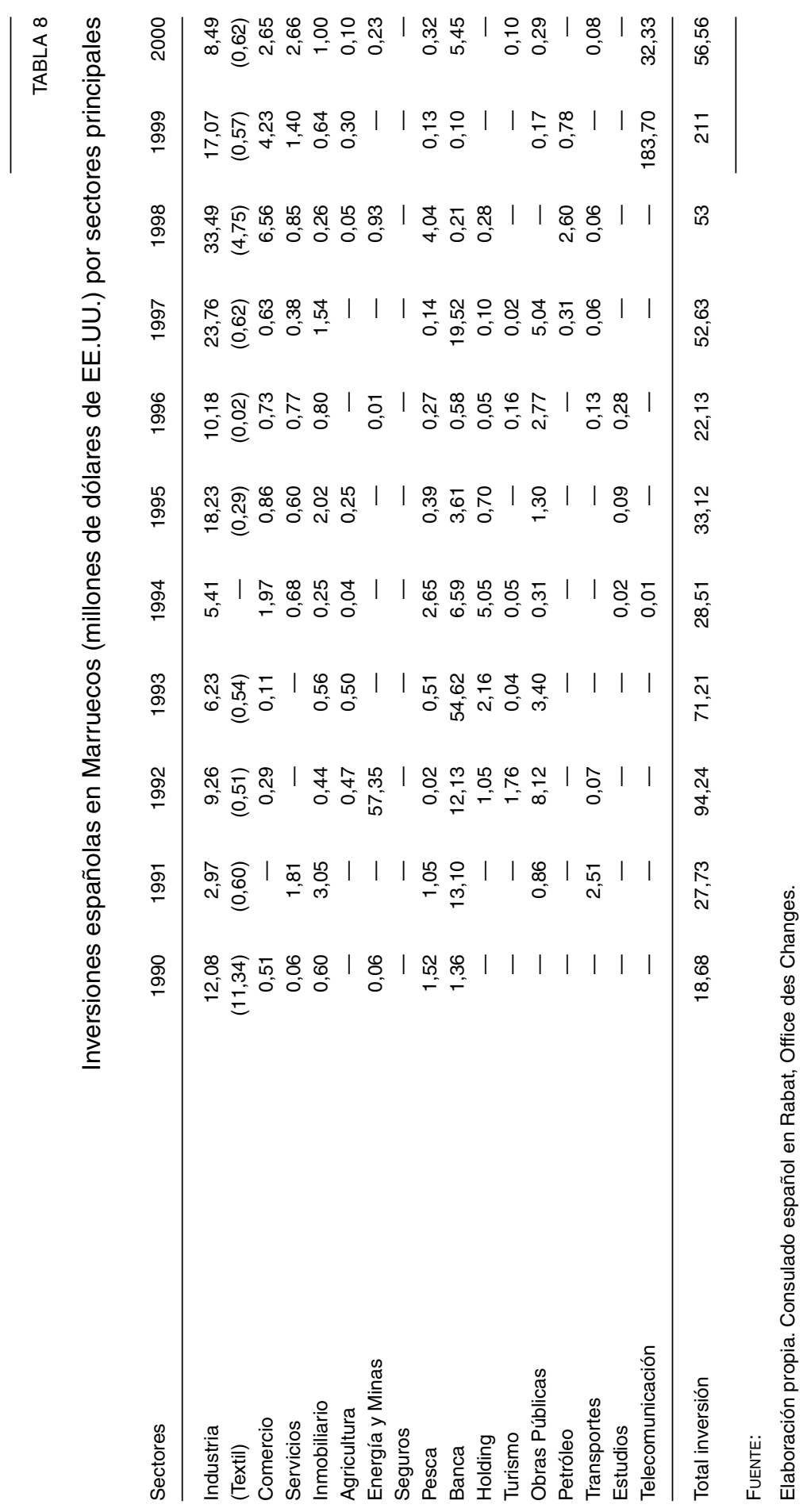


quía, más débil parece su capacidad de reaccionar a los impulsos que provienen del exterior» (Henry, 1990: 33) ${ }^{41}$.

En todo caso, hay que decir que, al igual que hace Izquierdo, Sassen, tras analizar la influencia de la inversión directa estadounidense en el extranjero ${ }^{42}$, pasa a considerar dónde se insertan los migrantes en el mercado de trabajo norteamericano, destacando que lo hacen principalmente en el sector servicios, y particularmente en las pequeñas industrias de servicios de ciudades como Los Angeles o Nueva York, en puestos de trabajo precarios, de lo que deducía Touraine que «la distancia entre los diversos países, y en el seno de la mayoría de los mismos, no deja de aumentar. Este hecho, de gran duración y amplitud, domina el final de nuestro siglo. El mundo, los países y las ciudades se dividen interiormente y con tanta rapidez que la comunicación entre ricos y pobres se vuelve imposible, como ha demostrado Saskia Sassen, que ha encontrado en todas las metrópolis del mundo unos elementos, por lo general muy minoritarios, relacionados con las ciudades globales, que no son ni Nueva York, ni Londres, ni Tokio, sino las redes de comunicación que se establecen a nivel mundial entre grupos de ricos e informados y cuyos principales lugares de interacción son las tres ciudades citadas» ${ }^{43}$.

Nos parece interesante seguir la pista de los flujos migratorios, pero no podemos olvidar los flujos de capital. La correlación existente entre inversiones directas provenientes del extranjero y emigración podría llevarnos más allá de la idea de que los flujos migratorios que se reciben en los países desarrollados tienen que ver con la demanda de trabajadores inmigrantes en los mercados de trabajo de esos mismos países. Esa idea es deudora del planteamiento de Marx cuando afirmaba que el volumen del ejército de reserva dependía en última instancia de las necesidades del capital, pues da por hecho que los intereses de los empresarios son unívocos, lo que es bastante dudoso, pues una cosa son los empresarios españoles que operan en España y otra los empresarios españoles que operan en Marruecos. Es posible que los segundos no tengan los mismos intereses que los primeros y que las leyes de extranjería tengan más que ver con las políticas de bienestar de los gobiernos que con los intereses de los empresarios que operan en España.

41 La traducción es nuestra.

42 Según Sassen, «los principales países que fomentan la inmigración se encuentran entre los primeros receptores de los trabajadores en los Estados Unidos y de la inversión extranjera directa norteamericana en las actividades de trabajo intensivo industriales y de servicios» (Sassen, 1993: 32). La inversión extranjera no contribuye a parar los flujos migratorios en los países del Tercer Mundo, sino justamente a lo contrario, actúa como un recurso para la movilidad. Estas empresas movilizan nuevos segmentos de la población hacia las migraciones regionales y de larga distancia. Las mujeres jóvenes que suelen emplear en las «zonas francas» es probable que en otras condiciones no hubieran entrado nunca en el mercado salarial. Si se quedan sin empleo no tendrán otra opción que la emigración. Lo que se postula es el efecto generalizado que producen las transnacionales contribuyendo a la formación de un grupo de emigrantes potenciales, al tiempo que la emigración aparece como una opción real.

43 Alain Touraine, en El País, viernes 23 de julio de 1999. 
Lo que queremos resaltar es que los gobiernos no están perdiendo poder respecto al control de poblaciones ni respecto a la expansión de sus economías, aunque sus actuaciones son hoy día más complejas. Por ejemplo, si se tienen en cuenta las relaciones entre España y Marruecos, se puede decir que las políticas demográficas restrictivas desarrolladas mediante la Ley de Extranjería de 1985 cumplieron sobradamente sus objetivos. Según un Informe de la Unión Europea referido a España, "sólo en 1998, se negó el visado de entrada a 760.836 marroquíes, frente a los 399.469 de 1997 »44. En este sentido podríamos decir que la política se impone a la economía, entendiendo por economía los intereses de ciertos empresarios que operan en España y que no encuentran mano de obra suficiente entre los autóctonos ${ }^{45}$.

Pero eso no quiere decir que el gobierno español no apoye decididamente a los empresarios españoles que operan en el extranjero. En este aspecto, los intereses del Estado y los de los inversores en el extranjero coinciden plenamente. En esta línea, tras la apertura de Marruecos a la economía internacional mediante la derogación de la ley de marroquinización, la liberalización del régimen de cambios, en 1989 España firmó con Marruecos un acuerdo para la promoción y protección recíproca de inversiones que entró en vigor en $1992^{46}$. Ese acuerdo, junto a otras actuaciones a las que nos referíamos en la tabla 5, debieron dar buenos resultados pues, en 1998, el Consejero Económico y Comercial de la Embajada de España en Marruecos invitaba a los empresarios españoles a invertir en un país con un marco legal y político estable, donde la rentabilidad de las inversiones españolas rondaba el $30 \% 47$. Como razones adicionales, afirmaba el Consejero que Marruecos supone un mercado potencial de 27 millones de consumidores, que el pueblo marroquí siente simpatía hacia los

44 El Mundo, miércoles 7 de julio de 1999.

45 Por ejemplo, durante el otoño del año 2001, los empresarios almerienses se quejaban de no encontrar trabajadores inmigrantes con permisos de residencia para poder emplearlos en sus invernaderos, a pesar de que había muchos marroquíes parados en la provincia. El funcionamiento real de la ley de cupos demuestra enormes insuficiencias pues no aporta soluciones al hecho de que los trabajadores que realmente emplean los empresarios no se están seleccionando en los países de origen, sino entre los que ya están en España, en muchos casos sin permiso de residencia.

46 Este tipo de acuerdo asegura un ambiente estable y favorable a la inversión, permite reducir los factores de incertidumbre política y jurídica que a menudo complican el desarrollo de los proyectos de inversión a los que se pueda enfrentar la empresa en el exterior.

47 Según escribía el Consejero en 1998, «la estabilidad de los indicadores macroeconómicos y la política de liberalización y fomento de la inversión extranjera aplicada por la Administración marroquí (con la derogación de la ley de marroquinización, la liberalización del régimen de cambios, la aplicación de un nuevo código mercantil y de una nueva Ley de Sociedades que se asemejan a las vigentes en la UE y, finalmente, la aprobación de la Carta de Inversiones a partir de enero de 1996) han sido factores adicionales que han animado a la empresa española a mirar hacia ese país con mayor interés. De hecho, los excelentes resultados obtenidos el año pasado se han visto favorecidos por la firma del acuerdo bilateral, en diciembre de 1996, que pone en marcha un mecanismo de conversión de deuda marroquí en inversiones, por un montante de 6.250 millones de pesetas y renovado el pasado 11 de diciembre de 1997, en 4.625 millones de pesetas más" (Martínez-Caro de la Concha, www.marruecos.net/Porquelnvertir.htm, consulta en noviembre 2001). 
logros alcanzados por España en materia de desarrollo económico, que en Marruecos existe una mano de obra barata, no muy cualificada, pero «con una sorpresiva capacidad de absorción de conocimientos y de técnicas modernas de producción», y que en Marruecos existe una abundancia de cuadros medios y altos con buena formación y a bajo $\operatorname{coste}^{48}$.

La propia Sassen se ha ocupado en los últimos años del papel de los Estados nacionales y los organismos privados en lo que se refiere a la economía global ${ }^{49}$. La preocupación de Sassen se centra principalmente en el análisis de las redes que se articulan en lo que denomina «ciudades globales», lugares de intercambio en los que, por ejemplo, están apareciendo nuevos intermediarios financieros que llegan incluso a suplir a los Estados u organismos internacionales en la función de supervisión de las empresas ${ }^{50}$.

Sin negar ese proceso, que sin duda define también los actuales procesos de globalización, consideramos que habría que poner más énfasis en el creciente papel de los Estados como incitadores de la globalización económica y paralizadores de los movimientos de población. La entrada de España en la Unión Europea, seguida de la firma de acuerdos internacionales con América Latina y países del Magreb, sugieren que no se ha producido una retirada del Estado del escenario internacional, sino más bien todo lo contrario. Ha aumentado la cantidad y complejidad tanto de las políticas migratorias como de las políticas exteriores.

48 El Consejero no olvida que «otro factor importante que debe ayudar al empresario español en su toma de decisiones es el hecho de que existe ya una presencia muy notable de empresas y empresarios españoles en Marruecos, así como la muy extendida red de Consulados y de instituciones educativas oficiales. En efecto, es importante señalar que el Estado español cuenta en Marruecos con 7 oficinas consulares repartidas por toda la geografía marroquí, así como una extensa red de colegios e institutos dependientes del Ministerio español de Educación que permite a la familia del expatriado español seguir sus estudios en el sistema educativo nacional» (op. cit.).

49 La autora se queja de que al tratar la globalización se ha reducido el papel de los Estados a meras víctimas de ese proceso. En su opinión, «uno de los papeles del Estado con respecto a la economía global actual, a diferencia de otras formas antiguas de la economía mundial, ha sido negociar la convergencia de las legislaciones nacionales y los factores extranjeros, ya sean empresas, mercados u organismos supranacionales. Lo que distingue a la fase actual es, por un lado, la existencia de un cuerpo legal sumamente elaborado que garantiza la exclusiva autoridad de los Estados nacionales sobre su territorio en una medida sin precedentes en el siglo XIX (...) y, por otro, la considerable institucionalización de los "derechos" de las empresas no nacionales, la "legalización" de un conjunto creciente y cada vez más institucionalizada de las organizaciones supranacionales en asuntos nacionales" (Sassen, 2000: 3 de 11).

50 Estos nuevos intermediarios, según Sassen, «empiezan a conformar un sistema privatizado de gobierno que garantiza el orden, el respeto de los contratos, la transparencia y la rendición de cuentas en el mundo de las transacciones comerciales transfonterizas. Hasta cierto punto, este mundo privatizado de gobierno ha reemplazado diversas funciones de los Estados nacionales como garantes de la protección de los derechos de las empresas. Introduce una nueva dinámica en la zona de interacción entre las instituciones nacionales y los actores globales. El Estado continúa realizando un papel crucial, pero ya no exclusivo, en la producción de "legalidad" en torno a nuevas formas de actividad económica» (Sassen, 2000: 6 de 11). 


\section{RECAPITULACIÓN}

En este artículo nos hemos ocupado de las conexiones entre las migraciones internacionales de nacionales de países en vías de desarrollo hacia países desarrollados y las inversiones que los países desarrollados realizan en esos países. En contra de lo que algunos autores afirman respecto a la irrelevancia de los Estados nacionales en las actuales circunstancias, nuestro objetivo era mostrar que en estos procesos el papel de los Estados sigue siendo fundamental.

Comenzamos nuestra exposición recordando los planteamientos de los economistas clásicos respecto a los flujos migratorios y los movimientos de capital. En general, los científicos sociales del siglo XIX propugnaban un intervencionismo estatal en favor de lo que se denominaba una «teoría dinámica de la colonización». A partir de los años setenta del siglo xx, las perspectivas que veían los flujos migratorios como algo positivo empiezan a dar paso a posiciones mucho más críticas que defienden que los Estados deben controlar los flujos migratorios, particularmente los que provienen de los países en desarrollo y se dirigen hacia los países desarrollados. Ésa sería una cara del proceso de globalización, que se refiere al creciente papel de los Estados en lo que toca al control de los flujos migratorios. Al mismo tiempo, los Estados occidentales juegan un papel como propulsores de la expansión económica, potenciando la inversión directa en el extranjero.

Hemos presentado datos sobre el proceso de globalización en el caso de España para señalar cómo el cambio de país de emigración hacia país de inmigración ha venido acompañado de un incremento de la inversión española en el extranjero en el marco de la pertenencia de nuestro país a la Unión Europea. A nuestro juicio, lo que realmente ha cambiado es el papel de España a nivel internacional.

Como hemos resaltado al analizar los datos, ese proceso es todavía incipiente. Sin embargo, cuando se observa la evolución de los flujos migratorios marroquíes hacia España y el aumento de las inversiones directas de España en Marruecos, se puede notar que, en la década de los noventa, las relaciones entre los flujos migratorios marroquíes y la inversión española en Marruecos se han alterado significativamente, y el papel del Estado español ha sido fundamental en ambos procesos.

En lo que toca a los movimientos migratorios de poblaciones que provienen de países en vías de desarrollo, España trata de poner límites al volumen de población y a sus derechos de ciudadanía. Sin duda, esta cara de la globalización de las migraciones no podía ser contemplada por los economistas clásicos. A finales del siglo xIx y durante una buena parte del siglo $\mathrm{xx}$, los Estados potenciaban la emigración pagando los pasajes de aquellos que po- 
dían acaparar sus incipientes políticas sociales, mientras que a finales del siglo xx son los Estados donde se recibe la inmigración los lugares en los que se desarrollan las políticas, en su mayor parte restrictivas.

En este sentido se puede decir que todavía no se ha llegado a producir un desmontaje de los Estados, como suele pensarse, sino todo lo contrario. El laissez-faire que los economistas clásicos reclamaban para los asuntos domésticos ha sido sustituido por un intervencionismo explícito que está contribuyendo a generar ciudadanos de primera y de segunda categoría en los países desarrollados.

Por el otro lado, el apoyo decidido de los gobiernos a sus inversores en los países en desarrollo sigue en aumento. Mientras que los economistas clásicos reclamaban que el gobierno británico pagara el viaje de los emigrantes para que los empresarios no tuvieran que asumir los costos de la expansión de su economía, los gobiernos actuales se ocupan de dar cobertura institucional a las actuaciones de sus inversores en el extranjero, unas inversiones que posiblemente generen más flujos migratorios ${ }^{51}$.

De modo que las migraciones constituyen la «pequeña factura» que en nuestros días tenemos que pagar los ciudadanos del Primer Mundo a cambio de que los empresarios de nuestros países «globalicen» el mundo. La gran novedad, a nuestro juicio, podría formularse diciendo que los grandes actores de la internacionalización de las economías han conseguido otros objetivos. Por ejemplo, en nuestros días parece que cualquier habitante del mundo desarrollado debe asumir la responsabilidad de unas iniciativas particulares que le son ajenas y de las que no está claro que se beneficie ${ }^{52}$. Y es que, aunque parece evidente que con la globalización ha llegado la crisis del Estado, lo único que en realidad está en crisis es el Estado del Bienestar.

\footnotetext{
51 Consideramos que sería de mucho interés desarrollar estudios concretos en los lugares de procedencia de los migrantes para poder documentar de qué modo concreto se articulan las redes de migrantes con las redes que se derivan de la presencia de personas y capital de origen extranjero. El peso que los autores (sobre todo antropólogos) otorgan a la red de conocidos del inmigrante en el país de origen como propulsores de nuevos flujos de migración, así como el papel de los medios de comunicación difundiendo la idea del «paraíso soñado», podrían relativizarse como consecuencia.
}

52 Nótese, por ejemplo, cómo autores como Bauman señalan que «cuando un ser humano sufre indignidad, pobreza o dolor, no podemos tener certeza de nuestra inocencia moral. No podemos declarar que no lo sabíamos, ni estar seguros de que no hay nada que cambiar en nuestra conducta para impedir o por lo menos aliviar la suerte del que sufre" (Bauman, 2001: 1 de 4) 


\section{REFERENCIAS}

ARANGO, Joaquín (2000): «Enfoques conceptuales y teóricos para explicar la migración», en Revista Internacional de Ciencias Sociales, n. ${ }^{\circ} 165$, pp. 3347.

BACARÍA, Jordi (ed.) (1998): Migración y cooperación mediterráneas, Barcelona: Icaria.

BAUMAN, Zygmunt (2001): «El desafío ético de la globalización», en www.elpais.es, edición impresa, 20 de julio.

BLANCO, Cristina (2000): Las migraciones contemporáneas, Madrid: Alianza Editorial.

CAMPA, José Manuel, y GUILLÉN, Mauro F. (1996): «Evolución y determinantes de la inversión directa en el extranjero por empresas españolas», en Papeles de Economía Española, n. ${ }^{\circ} 66$, pp. 235-247.

CASTELLS, Manuel (1975): «Inmigrant Workers and Class Struggles in Advanced Capitalism: the Western European Experience», en Politics and Society, vol. 5, n. ${ }^{\circ}$, pp. 33-67.

CASTLES, Stephen (2000): «Migración internacional a comienzos del siglo xxI: tendencias y problemas mundiales», en Revista Internacional de Ciencias Sociales, n. ${ }^{\circ} 165$, pp. 17-32.

CASTLES, Stephen, y KÖSACK, Godula (1985): Inmigrants Workers and Class Structure in Western Europe, Londres: Oxford University Press.

CASTLES, Stephen, y MILLER (1993): The age of migration: international movements in the modern world, Houndmills: McMillan.

CHEVASSU, Jean-Marie (1990): «Le rôle de l'État marrocain dans la croissance: le blocage et la reestructuration du secteur industriel», en Habib El Malki y Jean-Claude Santucci, État et Developpement dans le monde arabe, París: Éditions du CNRS, pp. 195-217.

CUADRADO ROURA, Juan R. (1975): Las migraciones extranjeras en España: una reconsideración, Málaga: Universidad de Málaga.

DEL PINO, Domingo (1990): Marruecos: Entre la tradición y el modernismo, Granada: Universidad de Granada.

DUNNING, John H. (1988): Explaining International Production, Londres: Unwin Human.

ENZENSBERGER, Hans Magnus (1992): La gran migración, Barcelona: Anagrama, Colección Argumentos.

GINER, Salvador, y SALCEDO, Juan (1976): «Un vacío teórico: la explicación causal de la migración», en Agricultura y Sociedad, n. ${ }^{\circ}$, pp. 113-126.

GOWAN, Peter (2000): La apuesta por la globalización, Madrid: Akal.

HABERMAS, Jürgen (2000): La constelación posnacional, Barcelona: Paidós.

HENRY, Jean-Robert (1990): “Les États maghrébins a l'épreuve de la mondialization», en Habib El Malki y JeanClaude Santucci, État et Developpement dans le monde arabe, París: Éditions du CNRS, pp. 31-38.

IZQUIERDO, Antonio (1996): La inmigración inesperada, Madrid: Editorial Trotta.

KOFMAN, Eleonore, y SALES, Rosemary (1992): «Towards Fortress Europe?», en Women's Studies International Forum, vol. 15, n. $^{\circ}$, pp. 29-39.

LÓPEZ, Bernabé, y otros (1993): Inmigración magrebí en España. El retorno de los moriscos, Madrid: Mapfre. 
MARX, Karl (1976): El Capital, Libro I, Tomo III, Madrid: Akal (ed. orig. 1867).

MASSEY, Douglas; ARANGO, Joaquín, y otros (1993): «Theories of International Migration: A Review and Appraisal», en Population and Development Review, 19, n. ${ }^{\circ}$ 3, pp. 431-466.

MORENO FUENTES, Francisco Javier (2001): «Migration and Spanish Nationality Law», en Randall Hansen y Patricia Weil, Towards a European Nationality, Nueva York: Palgrave, pp. 118-142.

PALAZUELOS, Enrique (1998): La globalización financiera, Madrid: Editorial Síntesis.

PETERSEN, William (1958): «A General Typology of Migration», en American Sociological Review, 23 (3), pp. 256266.

PIORE, M. J. (1979): Birds of Passage: migrant labour in Industrial Societies, Cambridge: CUP.

RAVENSTEIN, E. G (1885): «The Laws of Migration», en Journal of the Royal Statistical Society, 48, pp. $167-227$.

- (1889): «The Laws of Migration», en Journal of the Royal Statistical Society, 52, pp. 241- 301.

RUIZ DE OLABUÉNAGA, Jose Ignacio, y BLANCO, Cristina (1994): La inmigración vasca. Análisis trigeneracional de 150 años de inmigración, Bilbao: Universidad de Deusto.

SASSEN, Saskia (1993): La movilidad del trabajo y del capital. Un estudio sobre la corriente internacional de la migración y el trabajo, Madrid: Ministerio de Trabajo y Seguridad Social.

- (2000): «Para que funcione la economía global: el papel de los estados nacionales y los organismos privados», en http://www.unesco.org (consulta realizada en diciembre del 2001).

SIMON, Gildas (dir.) (1990): Les effets des migrations internationales sur le pays d'origine: le cas du Magreb, París: SEDES.

SOLÉ, Carlota (1976): Modernización: un análisis sociológico, Barcelona: Península.

SORA (2001): Actitudes hacia los grupos minoritarios en la Unión Europea. Un análisis especial de la encuesta Eurobarómetro 2000, Viena: Observatorio Europeo del Racismo y la Xenofobia.

STALKER, Peter (2000): Workers without Frontiers, London: Lynne Rienner Publishers, Inc.

STARK, Oded (1984): «Discontinuity and the Theory of International Migration», en Kiklos, vol. 37, 2, pp. $206-222$.

— (1993): La migración del trabajo, Madrid: Ministerio de Trabajo y Seguridad Social.

THOMAS, Brindley (1973): Migration and economic growth, London: Cambridge at the University Press (ed. orig. 1954).

TODARO, Michael P. (1988): El desarrollo económico del Tercer Mundo, Madrid: Alianza Editorial (ed. orig. 1985).

TOURAINE, Alain (1997): Pourrons-nous vivre ensemble?, París: Fayard.

ZOLBERG, Aristide R. (1989): «The Next Waves: Migration Theory for a Changing World», en International Migration Review, XXIII (3), Fall, pp. 403-30. 
In literature it is not usual to consider migratory movements and foreign investment together. In this article we intend to place Spain in the globalisation process concentrating on these two issues. In our point of view the profile of Spain has changed from a country of emigration to one where immigration predominates. This cannot be understood without considering the effect of internationalisation on Spain's economy since joining the European Union. We consider analysis of the combination of these two factors reflects retention of power by the state within the process of globalisation, although it's role has became more complex: on one hand developing polices to control migratory flows and on the other supporting the expansion of the economy in the world at large. As an example we focus on the relationship between Spain and Morocco over the last decade. 